\title{
EDITORIAL
}

\section{A Foreword from the Editor}

\section{Editor-in-Chief: Ji-Dong Gu}

School of Biological Sciences, The University of Hong Kong, Hong Kong

(Correspondence and offprint requests to: Ji-Dong Gu, School of Biological Sciences, The University of Hong Kong, Pokfulam Road, SAR, Republic of China, Email: jdgu@hku.hk)

http://dx.doi.org/10.18063/AEB.2015.01.001.

Biology, as an established subject of study and research, is without any doubt in its golden era since the structure of DNA was first deciphered back in 1950s. Due to the increase of human population as an apparently pressing issue facing our society, the broad biology plays a crucially important role in providing more food and natural materials by genetic and molecular manipulation of crops, controlling pathogens, protecting the environments and ecosystems through bioremediation and processes implemented in wastewater treatment plants and cleaning up of polluted sites. Medicines are manufactured by processes carried out by microorganisms by recombinant technology rather than directly extracting from animals or plants to decrease the cost and increase accessibility to the general public.

Biology, more specifically biotechnology, has contributed to the well-being of our society in an unprecedented manner. However, as pathogens to humans, livestock andcrops, and sources of contamination in natural lakes and coastal water, microorganisms also have many negative impacts to human life, available resources and the ecosystem. Nevertheless, microorganisms can offer great potential for new technologies to increase extraction capability of materials including precious metals and rare earth metals, and energy from traditional forms of energy reserves, e.g., petroleum, coal, oil, etc ${ }^{[1]}$. Obviously, new biological and biochemical processes through discoveries of new microorganisms can be made and implemented to manage wastes from industries, agriculture and municipalities more effectively in the future ${ }^{[2]}$.

Anthropogenic disturbances on Earth through indu- strialization and urbanization are unprecedented over the very short human history on earth and evolution, especially after the Industrial Revolution, but the impacts are strikingly visible everywhere. In the monumental book Silent Spring by Rachel Carson, the chemical dominated natural ecosystem is clearly presented to allow the environmental movement to flourish on a global scale. This trend of destruction will continue without much disagreement among people from vastly different backgrounds and professions because developing countries and the major population of the globe are striving for better living conditions, more consumption of resources, and accessibility to more commercial products including medicines and health care.

Since the dawn of industrialization, synthesis and refining of chemicals have become a main economy for inventions, economy, development, and human life, but they are also notorious for the pollution in water (hydrosphere), soils/sediments (lithosphere), air (atmosphere) as well as the organisms (biosphere) including human species ${ }^{[3]}$. Chemicals widely used in agriculture and industries are being controlled more and more strictly from not only their usage but also their production to protect the ecosystem, but new classes of chemicals are also emerging ${ }^{[4]}$. These chemicals, such as pharmaceuticals and personal care products, are used to maintain the quality of life, but they are also widely detected in rivers and coastal water and sediments, posing some relevant questions in environmental science and also ecotoxicology. Plasticizers are also important constituents in our daily life and humans are constantly exposed to them

A Foreword from the Editor. (C) 2015 Editor-in-Chief: Ji-Dong Gu. This is an Open Access article distributed under the terms of the Creative Commons Attribution-NonCommercial 4.0 International License (http://creativecommons.org/licenses/by- nc/4.0/), permitting all non-commercial use, distribution, and reproduction in any medium, provided the original work is properly cited. 
from birth. The effects from such exposure are suspected and valid data is needed to justify the regulation of plasticizers, especially on the basis of reproductive toxicology ${ }^{[5]}$. There is also the fast growing field of nanotechnology, which definitely offers many technological innovations and potential developments in a much wide range of industries and technologies, though undoubtedly there could be some negative issues about this new technology on the block. Its toxicity from the regulatory point of view has not been addressed so far.

History tells us a lot, but it also repeats itself unfortunately. As a platform of communication and dissemination of information, Applied Environmental Biotechnology (AEB) is committed to the publication and dissemination of original research papers, short communications, methods, reviews and also policy-related articles with a strong scientific basis to report not only about purely science, but also societal issues and new developments to allow new opinions to be reported. AEB would like to offer a fast publication without compromising on quality as our goal. At the same time, theme-based special issues are also solicited and organized to focus on specific research topics within the scope of the journal.

It is natural to question the necessity of a new journal such as Applied Environmental Biotechnology. Our understanding on this issue is strongly based on the fact that two-thirds of the world population is still living in the developing and under-developed countries and they are in the process of improving their lives through industrialization and urbanization. As this happens, environmental issues and their impact on the Earth will be surprisingly large to comprehend, as compared to the current level of knowledge and information. Continuous research and technological innovation will be essential to foster the development with technological advances in the future ${ }^{[6]}$.
This journal welcomes original research, short communication, methods, and reviews on new research breakthrough and also innovative technology with fast publication as our goal, without compromising the reviewing process and the quality of the research work for publication. Specific theme-based special issues on an identified topic relevant to this journal from conferences are also strongly encouraged.

\section{Funding}

Research in this laboratory has been supported by funding from Hong Kong SAR governments and RGC GRF and NSFC/GRC grants.

\section{References}

1. Mbadinga S M, Wang L Y, Gu J D, et al. 2011, Microbial communities involved in anaerobic degradation of alkanes. International Biodeterioration \& Biodegradation, vol.65(1): 113.

http://dx.doi.org/10.1016/j.ibiod.2010.11.009.

2. Gu J D and Wang Y, 2013, A new era for geomicrobial ecotoxicology in environmental science research. International Biodeterioration \& Biodegradation, vol.85: 345-346. http://dx.doi.org/10.1016/j.ibiod.2012.06.024.

3. Gu J D and Wang Y, 2013, Microbial transformation of phthalate esters: diversity of hydrolytic esterases, in Environmental Contamination-Health Risks, Bioavailability, and Bioremediation . Boca Raton, Florida: 313-346. http://dx.doi.org/10.1201/b12531-19.

4. Gu J D, 2014, Assessment of ecosystem health and ecotoxicology through chemical analysis and modeling. Ecotoxicology, vol.23(4): 475-479. http://dx.doi.org/10.1007/s10646-014-1206-x.

5. Kuenen J G, 2008, Anammox bacteria: From discovery to application. Nature Review Microbiology, vol.6(4): 320-326. http://dx.doi.org/10.1038/nrmicro1857.

6. Mitchell R and Gu J D, 2010, Environmental Microbiology, $2^{\text {nd }}$ edn, John Wiley, New York. 